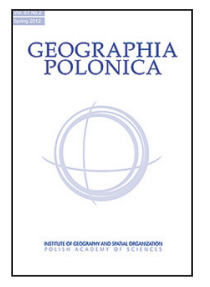

\title{
CRITICAL CONSIDERATIONS IN ACACIA MEARNSII ERADICATION: A CASE FROM SOUTH AFRICA
}

\author{
Geoffrey Mukwada $•$ Wisemen Chingombe • Phillip Taru \\ University of the Free State \\ Department of Geography \& Afromontane Research Unit \\ Private Bag X13, Phuthaditjhaba 9866: South Africa \\ *corresponding Author; e-mail: gmukwada@gmail.com
}

\begin{abstract}
Despite the huge investment that has been made in attempts to control Acacia mearnsii there is little evidence to show that the spread of this species is receding. In South Africa, Acacia mearnsii is regarded as one of the most problematic invasive species in wildlife conservation areas, where it is threatening ecosystem health. This paper examines the distribution of Acacia mearnsii in an area that is adjacent to the Golden Gate Highlands National Park in South Africa. The results of the study indicate that the park is under threat from invasion by the species. This paper recommends the adoption of an integrated approach in which economic, social and environmental assessments are factored into eradication programmes.
\end{abstract}

\section{Key words}

conservation • eco-agricultural landscapes $\bullet$ ecosystem goods and services $\bullet$ integrated control $\bullet$ invasive alien species $\bullet$ poverty

\section{Introduction}

Despite the huge investment that has been made in attempts to control and eradicate the black wattle (Acacia mearnsii) there is little evidence to show that the spread of this species will be reversed within the foreseeable future. Though substantial literature on mountain-based ecosystems in South Africa now exists there is little evidence suggesting that the invasion of montane based national parks by invasive alien species
(IAS), including Acacia mearnsii, has been given sufficient research attention. Parks are protected areas of immense importance to wildlife conservation. Globally, protected areas such as national parks have been the mainstay of conservation strategies since the beginning of the 20th century, though their social impact only began to be widely recognized in the 1970s (Adams \& Hutton 2007). Because of their conservational value, as well as their importance as wildlife tourist destinations (Teel et al. 2010) parks need to be 
protected from bio-invasion so that their integrity is maintained.

IAS can be defined as those non-native species that threaten ecosystems, habitats or species and are considered as key drivers of human-caused global environmental change, the impact of which has been "heralded as the second greatest agent of species endangerment and extinction after habitat destruction" (Pejchar \& Mooney 2009: 497). IAS have a wide range of effects in the environment, including reduction of surface water runoff, groundwater recharge, livestock production and biodiversity in terrestrial biomes (van Wilgen et al. 2007), and are therefore capable of disrupting ecosystem services. Ecosystem services are the functions and products of ecosystems that benefit people or yield welfare to society (Lele et al. 2013). For this reason invasion of national parks by these species has the capacity to cause serious negative and at times irreversible consequences on both ecosystems and rural livelihoods.

In South Africa, considerable investment has been made to reduce IAS invasion. Of the 3.2 billion rand (approximately US $\$ 200$ million) that the Working for Water Programme spent on control of invasive species between 1995 and 2008, the largest portion, accounting for 561.9 million rand (approximately US\$35 million) was spent on the control of Acacia mearnsii, but despite this huge expenditure there is no indication that the extent of the invasion by this species has abated (van Wilgen et al. 2012). Richardson and van Wilgen (2004) note that though the Working for Water Programme was initially designed to restore watersheds and riparian areas only, it has been extended to all natural and semi-natural ecosystems to become one of the world's biggest programmes dealing with IAS. However, it must be noted that the Working for Water Programme has been successful with respect to other IAS. This success has been attributed to the project's multi-faceted and cross-disciplinary nature that has enabled it to leverage local and international funding, continuing political support and its focus on multi-disciplinary ecological, hydrological, social and economic goals (Richardson \& van Wilgen 2004). However, not even the development and application of more sophisticated approaches of decision making has solved the problem of IAS invasion. This especially applies to Acacia mearnsii. For example, Forsyth et al. (2012) have cited the application of the multi-criteria decision making which allows for multiple objectives and constraints to be simultaneously considered in relation to IAS control.

Previous attempts by the Working for Water Programme to eradicate Acacia mearnsii from the Golden Gate Highlands National Park (GGHNP) and the surrounding areas did not register much success and many of the areas from which the species was once eliminated have been recolonized. Mechanical and chemical control methods were used in these attempts (SANParks 2012). The recolonization of areas from which the species had been cleared suggests that these control measures have been largely unsuccessful. Mechanical and chemical control methods may have also caused unintended environmental effects through stream bank destabilization and water pollution along watercourses. Thus, even though the invasion of an area by $\mathrm{Aca}$ cia mearnsii has deleterious environmental effects, the measures that are often taken to eradicate the species can be equally environmentally damaging. There are three basic categories of methods that are normally employed to control Acacia mearnsii. These are mechanical, chemical and biological methods. Mechanical methods involve the physical destruction of trees, including cutting, hand pulling, hoeing and burning. The Working for Water Programme relied largely on mechanical methods. These methods have hardly succeeded because Acacia mearnsii can easily regenerate from its root stock while use of fire creates an invasion window that breaks the dormancy of the seeds and facilitate germination (Moyo \& Fatunbi 2010). Chemical control involves the application of arboricides, while biological control depends on biological agents that can eliminate a species, for example mycoherbicides. In South Africa, none 
of these methods have proved to be effective in controlling Acacia mearnsii. Moyo and Fatunbi (2010) have suggested an integrated approach in which mechanical, chemical and biological methods are applied simultaneously. However, the application of chemical and biological agents has the potential to cause environmental damage, particularly along watercourses. Digging destabilizes stream banks while use of chemicals pollutes streams and endanger untargeted species.

Acacia mearnsii occupies status 2 on the Conservation of Agricultural Resources Act (CARA) list of invasive species (RSA 1983; SANParks 2013). This makes the eradication of the species the legal obligation of the SANParks, as well as its priority. However, Acacia mearnsii can yield benefits that can uplift rural livelihoods. These benefits include the supply of products such as fuelwood, phytomedicines, construction materials, among other products.

This paper addresses three key questions. The first is about how Acacia mearnsii is distributed in the GGHNP and whether there is evidence showing that the species is posing danger to the park. The second relates to why it should be considered necessary to eradicate the species when previous attempts to do so have either failed or, worse still, led to undesired social and environmental consequences in the past. The third question examines whether the control or eradication of Acacia mearnsii can be done in a way that benefits the poor communities living around the GGHNP under those circumstances where the eradication of the species is deemed necessary. Accordingly, the purpose of this study is to examine the dilemma facing conservationists and policy makers in their attempts to control Acacia mearnsii, which is posing a threat to habitats in the Golden Gate Highlands National Park in South Africa. On the one hand Acacia mearnsii is an IAS that undermines environmental integrity in national parks and disrupt ecosystem services, while on the other it creates new habitats that favour the survival of some species and generate livelihood benefits. This creates a dilemma on whether Acacia mearnsii should be completely eradicated or not. The paper seeks to address two objectives. This first objective is to establish the patterns of the distribution of Acacia mearnsii and assess the potential risks posed by the invasion of the park by the species. The second objective is to explore alternative approaches of managing $\mathrm{Aca}$ cia mearnsii in the park while improving the livelihoods of local communities.

\section{Impact of Acacia mearnsii on the environment}

Even though human-imposed barriers have been erected around protected wildlife areas such as national parks, conservation in these areas remains susceptible to invasive alien plant species. In South Africa, where Acacia mearnsii has invaded more than 2.5 million hectares of land in riparian and forest areas, as well as rangelands (Moyo \& Fatunbi 2010), the species can also be considered as one of the most problematic IAS in protected wildlife areas.

Like most invasive species, Acacia mearnsii has the ability to survive, reproduce and spread unaided, usually at a rapid rate such that it displaces the indigenous vegetation, often with serious economic, social and environmental consequences. Once they have invaded an area and become established, IAS alter the environment and make it difficult for the native species to survive, by altering the structure of the plant community (Liu et al. 2012) and by transforming the ecosystem function (Drury et al. 2007). Habitat disturbance by human activities, often facilitates bio-invasion (Alofs \& Fowler 2010). For example, overgrazing and burning encourage the proliferation of Acacia mearnsii (Moyo \& Fatunbi 2010).

While a species can be prevented from becoming an invader by a human-imposed barrier, there is a variety of mechanisms by which the species can breach the barrier (Blackburn et al. 2011). A number of factors contribute to the breaching of humanimposed barriers in national parks, some 
of which are linked to the physiological properties of the invasive species, while others relate to the impact of human activities on the ecosystem, especially where the impact leads to the disturbance of ecosystem health. Foxcroft (2009) argues that although invasions by IAS are normally considered to be unidirectional in that they progress from an initial founding population to become widespread, the flourishing of most invasive species tends to fluctuate in accordance with drivers such as rainfall and environmental disturbance. Moyo and Fatunbi (2010) have established some of the factors that make Acacia mearnsii a successful invader and enable it to breach human-imposed barriers. These factors include Acacia mearnsii's capacity to alter the habitat through mineral enrichment brought about by copious litter leaf decomposition (Campbell 2000), its capacity to produce large numbers of seeds and its ability to produce suckers. The seeds can lie dormant in the soil for a long time and germinate only when veldt fires break that dormancy. Also, the species produces dehiscent pods starting from the end of its short juvenile phase, which lasts about two years. Because of their small size the seeds can be easily transported by runoff, wind or by animals. Acacia mearnsii is also usually a successful invader because even though it is a short-lived plant it is fast growing. The species normally outcompetes native species for water, soil nutrients and organic matter (Ogden \& Rejmánek 2005). It also disrupts the hydrological balance of an area by promoting high evapotranspiration rates. High evapotranspiration rates lower the water table and promote soil desiccation, which in turn leads to the elimination of shallow rooted plants.

\section{Livelihood opportunities associated with Acacia mearnsii}

Research conducted elsewhere has shown that Acacia mearnsii can yield some benefits since it is a source of a variety of products, including fuel, medicines and livestock fodder.
Thus, while the elimination of Acacia mearnsii seems to be desirable there are benefits that communities living in areas abutting national parks can derive from the species, especially in densely populated poverty stricken areas. Firstly, the control of the species is labour intensive, and is thus a source of employment. This is particularly so in the developing world where unemployment rates are high. The Working for Water Programme which was launched in South Africa in 1995 has created hundreds of jobs across the country. Secondly, being a species with economic value Acacia mearnsii is a source of important products that possess a market value. Examples, are mine props, construction poles, tool handles, matchwood, furniture, as well as joinery and flooring products (DWAF 1997). It is an important source of fuel in many parts of the world, including Kenya and Brazil where it is used to produce charcoal (Moyo \& Fatunbi 2010). The tree also has medicinal properties. It can be used as a styptic or an astringent (Rouget et al. 2002). It plays an important role in soil protection and stabilization. Because of its capacity to grow quickly, as well as to fix nitrogen in the soil, it can promote soil enrichment, making it an important component of agroforestry systems. Its foliage has proved to be a viable source of green manure, while it is an attested source of fodder for supplementing cattle feed during drought periods.

\section{Materials and methods \\ Description of the study area}

This study was conducted in the GGHNP and a neighbouring tribal area. The area is situated in the eastern part of the Free State Province of South Africa, and located in the foothills of the Maluti-Drakensberg Mountains, between $28^{\circ} 27^{\prime} S-28^{\circ} 37^{\prime} S$ and $28^{\circ} 33^{\prime} \mathrm{E}-28^{\circ} 42^{\prime} \mathrm{E}$. The types of vegetation found in the area include the Sandy Grassland, Basotho Montane Shrubland, Northern Drakensberg Highlands Grassland, Lesotho Highland Basalt Grasslands and Drakensberg-Amathole, as well as the Afromontane Fynbos (SANParks 2012). In the GGHNP itself 
is the Wet Cold Highveld Grassland, a type of mountain grassland characterized by poor species richness, with Hyparrhenia hirta being the dominant species (SANParks 2008). This is predominantly found on the dry hot north facing slopes. Other dominant species include Eragrostis species, Tristachya leucothrix and Themeda triandra (SANParks 2012).

By contrast, the relatively moist, steep, cooler, south facing slopes are richer in species composition and are characterized by dense thickets with sparse undergrowth that is dominated by a non-grassy herbaceous layer (SANParks 2008). However, some of the plant species that are found in the park are exotic, including invasive ones such as Eucalyptus sp. and Acacia mearnsii. While the former has almost been totally eradicated from the park, the latter is posing a major threat to biodiversity. The park has a diversity of wildlife species, including antelopes, carnivores, amphibians and birds. Some species that are found in the park are endemic to the region, for instance the sun gazer (Cordylus giganteus), while others are rare or endangered, for example, the bearded vulture (Gypaetus barbatus), grass owl (Tyto capensis) and Bald Ibis (Geronticus calvus) (SANParks 2012). The high biodiversity of the park makes it attractive to tourists and scientific researchers.

Like in most other parts of the eastern Free State, local communities are characterized by high levels of unemployment and poverty. These communities comprise former farm workers who remained in the park or on adjacent land when farmland was incorporated into the park. Communal grazing is the main land use practiced in the area abutting the park. Little or no consideration was made to compensate the farm inhabitants, mostly farm labourers who had lived and worked on the incorporated farms for decades (Slater 2002). The South African constitution prohibits the arbitrary eviction of these communities or their offspring and they may not be relocated unless a more suitable home is found for them. Often park-community conflicts arise when these communities break park laws or regulations. One area of conflict relates to the controls that park authorities impose on resource harvesting. Though park authorities allow local communities to harvest resources such as grass, medicinal plants and other products the communities want unfettered access to these resources, including pastures for their livestock. Unfortunately, it is this uncontrolled movement of people and livestock that promotes the invasion of the park by Acacia mearnsii, and will thus have a detrimental effect on biodiversity, habitats and ecosystem services in the park.

\section{Sources of data}

Two types of data were used in this study. The first type was remote sensing data which was used to determine the distribution of Acacia mearnsii in the area abutting the GGHNP in order to get a general idea about whether the species was a threat to the park or not. Spot 5 satellite images were used for that purpose. The areas where Acacia mearnsii is prevalent were identified through unsupervised classification of the satellite images and ground truthing. The second type of data that was used was field data which was collected through transect surveying and questionnaire surveying, to determine the density of the species and the views of the local community about the control of the species, respectively. Figure 1 shows the location of the transects that were surveyed. The transects were generally north-south in orientation and were approximately 200 metres apart. The survey involved a tree inventory to determine the number of trees of different species in sampled squared plots. The plots were $10 \times 10 \mathrm{~m}$ in size and were located 20 metres apart. The number of black wattle trees for both the mature and juvenile trees were recorded in each plot. Given that each plot was $100 \mathrm{~m}^{2}$ and also that $10,000 \mathrm{~m}^{2}$ constitute a hectare, tree densities per hectare were calculated by simply multiplying the number of trees in each plot by 100 . The resultant tree densities were then assigned to the mid-points of the plots, the distances of which were 
determined from the park boundary and plotted on a graph.

The questionnaire survey was conducted in the village (Fig. 1) to establish the activities that the community in the tribal area adjacent to the GGHNP undertake which might promote the spread of Acacia mearnsii in the park. The questions that were included in the questionnaire solicited the views of the villagers regarding the use and control of Acacia mearnsii, as well as the benefits of controlling the invasion. Other questions related to the environmental problems arising from the control of the species. The questionnaire survey took the form of a census and included all the household heads who were present in the village when the survey was conducted. Altogether, 11 household heads responded to the questionnaire.

\section{Results}

\section{Distribution of Acacia mearnsii in areas around the GGHNP}

The major areas in which Acacia mearnsii is prevalent are shown in Figure 1. However, micro-level variations occurred along each of the surveyed three transects (Figs. 2-4).

At all locations along Transect 1 the density of juvenile trees is less than that of mature trees. The exception is the stretch between 200 and 230 metres from the park, where the number of juvenile trees far exceeds the number of mature trees. The density of juvenile trees in this area is more than 30 times higher than that of mature trees.

The analysis of inventory data collected from Transect 2 shows that the recruitment

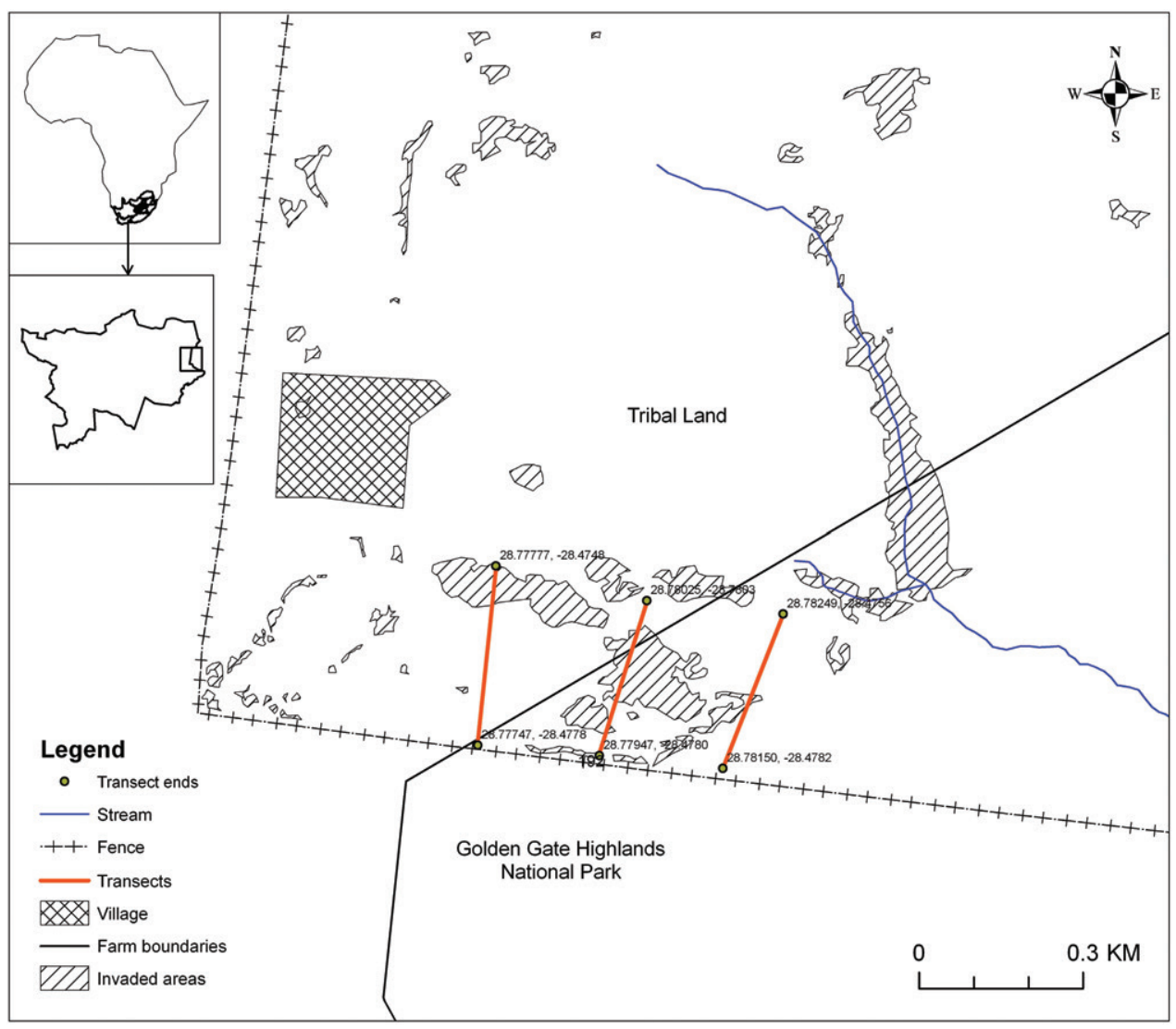

Figure 1. Distribution of Acacia mearnsii in the study area, showing how the species is spread across part of the tribal area around the village 
ratio is much higher along this transect than along the first transect. There is evidence of colonization in areas where the species did not previously exist. This occurs at about 50 metres from the park. Within 200 metres from the park tree densities along Transect 2 are much higher compared to those recorded at corresponding distances along Transect 1.

Along Transect 3, tree densities were relatively low in areas which were previously cultivated and those where trees were previously eradicated. Recruitment ratios are very high along the transect and in some cases the population of juvenile trees far exceeds the population of mature trees, especially within the first 10 metres from the park, as well as beyond 250 metres.

Overall, at corresponding distances from the park tree densities are lower along Transect 3 compared with the other two transects. The highest tree densities were recorded along Transect 2, where tree densities

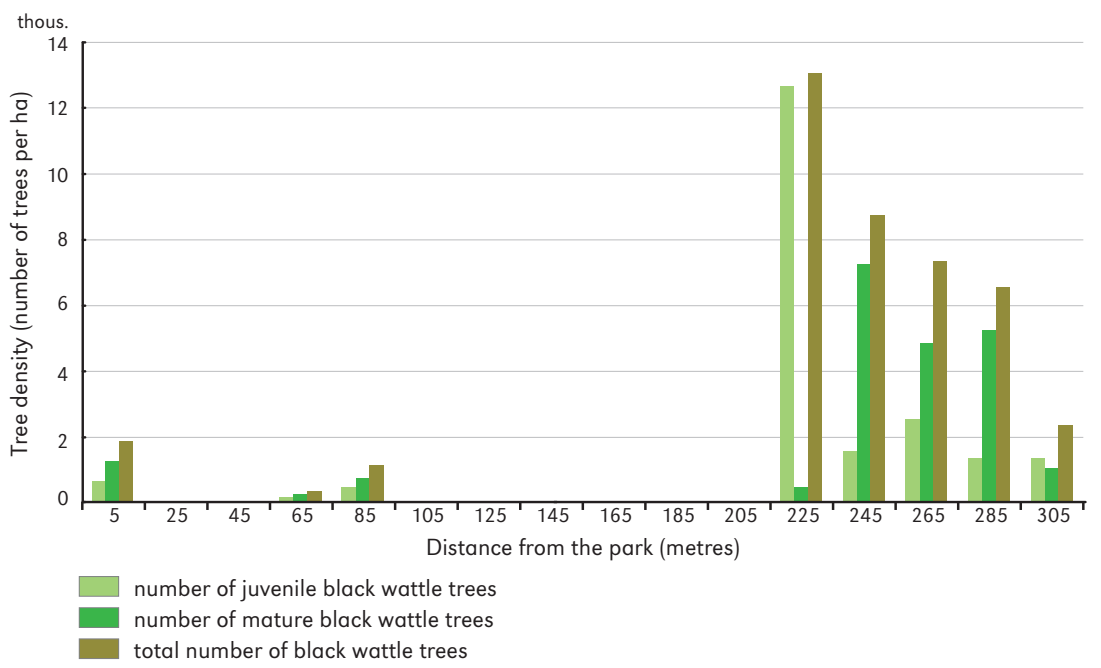

Figure 2. Distribution of Acacia mearnsii along Transect 1

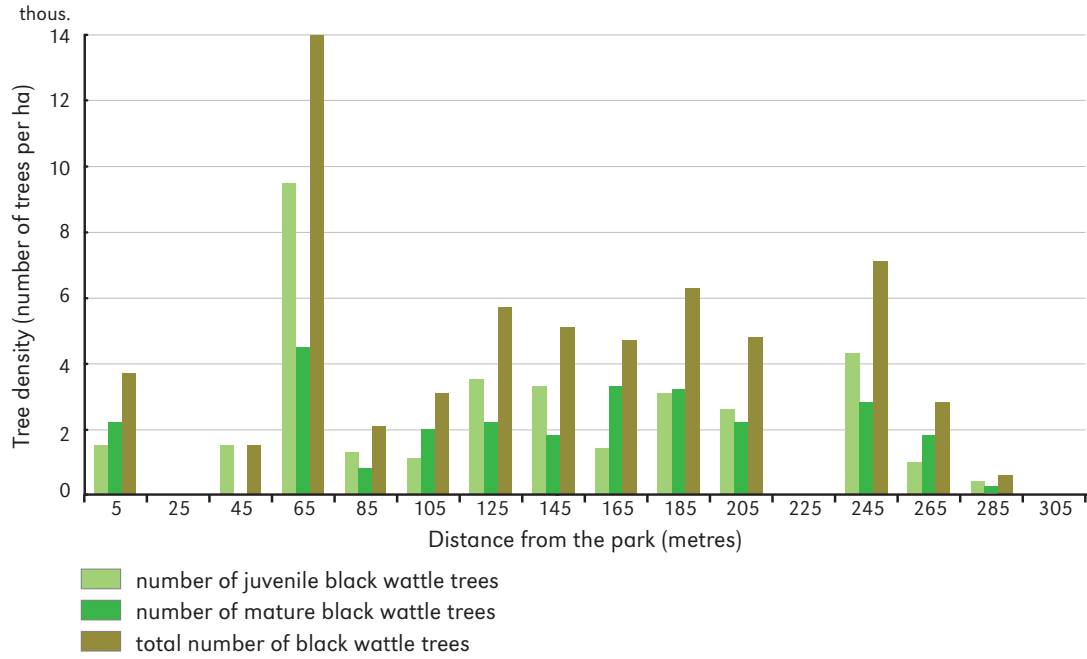

Figure 3. Distribution of Acacia mearnsii along Transect 2 


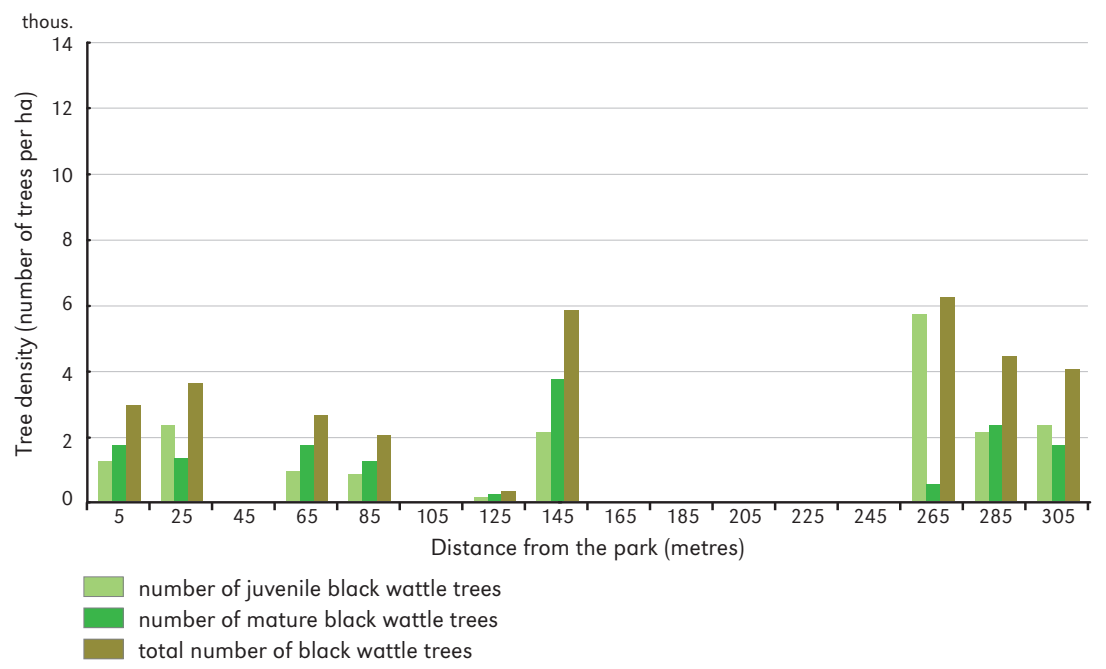

Figure 4. Distribution of Acacia mearnsii along Transect 3

reach 14,000 per hectare between the distance of 50 and 75 metres from the park. The proliferation of the black wattle has the potential risk to change the dynamics of the natural ecosystem in the GGHNP. Also, Acacia mearnsii is the dominant tree species within the communal grazing area adjacent to the park. Other notable tree species found in the area included Leucosidea sericea, Euclea spp. and Cussonia spp., though they occur in negligible numbers. In some areas the densities of Acacia mearnsii is so high that other plants hardly exist. In these areas there is virtually no undergrowth. However, there is a conspicuous mat of leaf litter. This means that the invasion of the park by the black wattle has the potential to undermine ecosystems health because the species suppresses the growth of other species, including graminoids, thus undermining the quality of pasture and worsening food supply for herbivores, obviously disrupting trophic structures within the ecosystem. Within the study area, invasion of the park has already started along places that are adjacent to the fence, along the boundary of the park (Fig. 5).

Within the area adjacent to the park there is a high population of juvenile trees. As shown by data from the transect survey, there are areas where Acacia mearnsii is spreading rapidly. Data from the transect survey shows that in these areas the population of juvenile trees is far higher than the population of mature trees. There is also an evidence showing that some places have been recently colonized, possibly for the first time. The areas that are most susceptible to invasion are those bordering the main enclaves of Acacia mearnsii (Fig. 1). Most of the recently invaded areas are found in old fields, along the southern flanks of the tribal area, where cultivation is no longer practiced. Among such areas are places characterized by low densities of mature trees (Figs. 2 and 4). However, juvenile trees of Acacia mearnsii already exist inside the park. The spread of Acacia mearnsii is likely to undermine the touristic potential of the park, which is one of the ecosystem goods provided by the park. In some parts of the communal grazing area that lie next to the GGHNP the concentration of Acacia mearnsii is considerably high, especially along the river and the gullies (Fig. 1). The inaccessibility of these places makes the control of the species problematic. The gullies are mostly concentrated in areas where headward erosion has been active. In areas where densities of Acacia mearnsii are high, erosion is less active, showing that the species has a stabilizing effect on soil, thus 


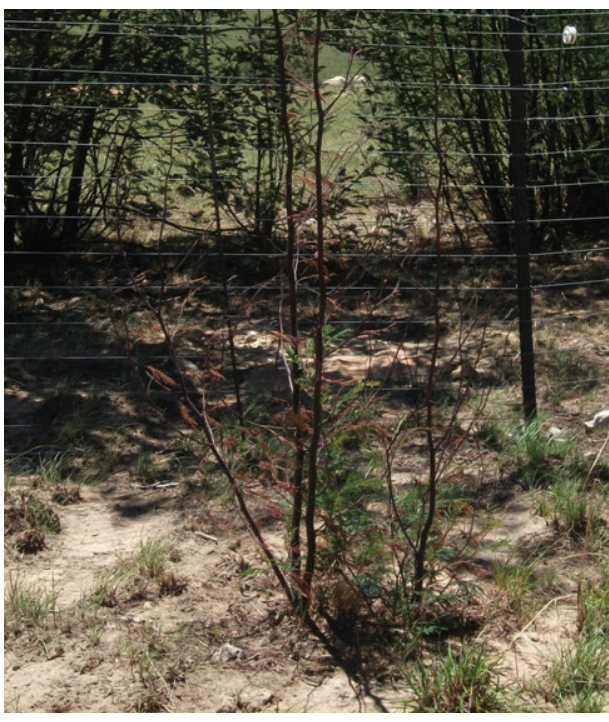

Figure 5. In the foreground is an area where juvenile trees of Acacia mearnsii have recently breached the human-made barrier and may soon spread into the rest of the park. Within a few metres from the fence (as shown in the background) is a stand of Acacia mearnsii from which the species is spreading

preventing the undercutting of the stream banks by meandering streams. In these areas the soil would be loosened and water erosion would be worse if the trees were cut. This would also cause siltation and affect riparian ecosystems downstream. In addition to these advantages Acacia mearnsii also plays an important role in maintaining the population of pollinators, including bees and other insects. In November, when the transect survey was conducted, the species was in flower when most other species were still dormant. This is one of the traits of Acacia mearnsii which makes it a successful invader. However, if the species is left completely uncontrolled, ecosystem goods and services, including the capacity of the ecosystem to supply products such as grass, phyto-medicines and its ability to support ecotourism will be undermined. Along all the three transects there is evidence suggesting that some sites were previously cleared. This evidence includes tree stumps, ash and charcoal.

\section{Villagers' views regarding the control and eradication of Acacia mearnsii}

Villagers' views varied remarkably regarding the control and eradication of Acacia mearnsii. The species plays an important role in their livelihoods. When responding to the question whether they considered the species to be a problem or a resource, eight (73\%) of the villagers indicated that the species was a resource. All the household heads who took part in the questionnaire survey stated that they use it as a source of firewood. Asked whether the species should be conserved or eradicated six (55\%) of the villagers preferred that the species be conserved. These responses are not surprising, considering that nine $(82 \%)$ of the villagers fall within the 0-2000 rand (0-188.20 US\$) monthly income bracket, and are thus unable to afford energy requirements for lighting, cooking and heating. Several sites were identified where Acacia mearnsii was recently harvested for sale or household use. At some sites poles or fuelwood were stacked into piles that were waiting for transportation to markets in the nearby town of Phuthaditjhaba.

Most of the harvesting takes place in accessible areas, especially those that are close to the village and the main tracks. However, most of the villagers were aware of the impact that Acacia mearnsii has on the environment and the effect that it has on other species, especially grasses. Seven (64\%) of the villagers noted that grass no longer grows in areas where the species is well established. This explains why seven (64\%) of the villagers now graze their livestock in the park. There are areas where the villagers have damaged the fence to facilitate the entry of their livestock into the park. Only five (46\%) of the villagers noted that the presence of the species is promoting erosion, and another five indicated that areas where stands of Acacia mearnsii exist are prone to fire damage, though none of them reported the siltation of rivers and the displacement of native trees, or the drying of streams, as a result of the proliferation of the species. 
A negligible number of household heads were aware of the different ways through which Acacia mearnsii spreads. Only one household head was aware of the role that livestock can play in the dispersal of the seed, and only three household heads stated that running water can promote the dispersal of the species. Responses from most villagers did not indicate that they were aware of the benefits of eradicating Acacia mearnsii. Table 1 shows the views of the respondents regarding the control of the species.

It is ironic that even though the majority of the villagers did not agree that Acacia mearnsii control programmes are beneficial, they strongly agreed that their community should be involved in these programmes. Surprisingly, when the villagers were asked to state some of the measures that can be taken to eradicate Acacia mearnsii, seven (64\%) and eight (73\%) made reference to chemical and mechanical measures, respectively. This high awareness among the villagers is not surprising because they were familiar with the earlier efforts by the Working for Water Programme to control the species.

\section{Discussion}

As shown in the preceding section, the risk of the invasion of the GGHNP by Acacia mearnsii is high. This will have serious consequences on ecosystem health within the park. Data from transect analysis clearly shows that densities of Acacia mearnsii in areas abutting the park range between
2000, along Transect 1 (Fig. 2) to about 4000 along Transect 2 (Fig. 3). As noted earlier, the zone that is immediately adjacent to the park is supposed to be an IAS free buffer zone, in line with the GGHNP management plan. With the buffer zone already infested, there is no doubt that the species can now easily spread into the park. This suggests that previous efforts to control the species by creating a buffer zone within which Acacia mearnsii is monitored around the park have proved to be ineffective, despite the investment that was undertaken in this initiative. This is consistent with Luque's et al. (2013) argument that even though there now exists a large, dedicated community of researchers and managers worldwide, management successes against IAS are still outnumbered by new introductions. Luque et al. (2013) maintain that despite our improved knowledge about the harm IAS can cause, better management procedures to prevent new introductions and more efficient eradication protocols, IAS remain problematic. Evidence from the current research study indicates that successful IAS eradication protocols are based on an integrated approach where livelihood needs of local communities and ecosystem services are taken into consideration.

\section{Integrated approach to Acacia mearnsii control}

As demonstrated by the findings of this research Acacia mearnsii invasion is a multifaceted problem requiring a multi-faceted

Table 1. The views that villagers hold about the Acacia mearnsii and its eradication

\begin{tabular}{|c|c|c|c|c|c|}
\hline \multirow[t]{2}{*}{ Statement } & \multicolumn{5}{|c|}{$\begin{array}{c}\text { Extent to which villagers agree } \\
\text { with the statement and the num- } \\
\text { ber of villagers who gave } \\
\text { the response }\end{array}$} \\
\hline & SD & D & $N$ & A & SA \\
\hline The control of the black wattle can create jobs & 5 & 1 & 1 & 3 & 1 \\
\hline The control of the black wattle can generate income & 3 & 3 & 0 & 4 & 1 \\
\hline The black wattle can improve pastures in future & 2 & 4 & 0 & 2 & 3 \\
\hline The local community should be involved in black wattle eradication programmes & 1 & 0 & 3 & 0 & 7 \\
\hline
\end{tabular}

Explanations: $S D=$ strongly disagree; $D=$ disagree; $N=$ neutral; $A=$ agree; $S A=$ strongly agree 
solution. This is because conservation issues rarely occur in isolation (Adams \& Hutton 2007) due to the fact that rural livelihoods are structured by many forces, including some that are linked to external factors such as those that have an influence on the broader economy (Riddell 2013). In the case of the GGHNP Acacia mearnsii eradication project, one important external factor that should be considered alongside the control of Acacia mearnsii is the government funded Expanded Public Works Programme (EPWP). The EPWP involves the hiring of unemployed community members in public works projects such as construction or maintenance of roads and fire guards. The EPWP is a public job creation initiative that was introduced by government in 2004 (Antonopoulos 2009). Financial resources from the EPWP could be used to employ some villagers in the eradication of the species, thus simultaneously addressing both unemployment and poverty at the same time. The integrated control measures that were previously employed in the study area did not eradicate the problem or reduce the imminence of invasion. Previous integrated control measures simply involved the application of mechanical methods such as uprooting of invasive species and chemical control methods like use of arboricides. This is evidenced by the recolonization of Acacia mearnsii in areas from which it was previously eradicated within the buffer zone. Buffer zones are areas within which land use change may have an influence on the current or future state of the park (SANParks 2013). The 2013-2023 GGHNP management plan shows that there is a buffer of at least 3 kilometres right round the park, though the width varies in every direction. We argue for a different kind of integrated approach, encompassing multiple stakeholders such as local communities, government departments, SANParks, tribal authorities, NGOs and industry in which the needs of local communities are accommodated. Such an approach is similar to that which was proposed by Prévot-Julliard et al. (2011) who advocated conservation and management strategies that are flexible and capable of being adjusted to society's needs. We argue therefore that the control of Acacia mearnsii should not be solely based on biological arguments, but also on social and economic considerations. In line with this argument, Liu et al. (2011) highlighted the need to incorporate social values in decision making when managing invasive alien species. This makes a strong case for the inclusion of multiple players in programmes that are meant to address the problem.

In the proposed integrated approach there are a number of crucial issues that make total eradication of Acacia mearnsii undesirable. First, as noted above, the species is important to the livelihoods of rural communities, including those located in nearby villages and informal settlements. However, where it is absolutely necessary to eradicate the species, people from these communities should be accorded first priority when employees are hired to perform this role. As shown in the results of the questionnaire survey, most of the people from the tribal village community (Fig. 1) are either unemployed or low income earners. This explains the relatively high number of villagers who indicated that they are willing to participate in Acacia mearnsii eradication projects despite the fact that they perceive the species as an important livelihood resource. Their involvement in the eradication projects would be a vital source of household income. This confirms the applicability of the notion of social desirability bias which was coined by Schüttler et al. (2011) to express the compromises that local communities often make to the point of accepting eradication programmes because of the social benefits derived from the programmes. One of the most important social benefits generated by IAS eradication projects is employment. In this regard, labour intensive approaches involving mechanical and chemical methods of Acacia mearnsii control may have to be considered as an integral part of the already existing development programmes, especially the EPWP.

Secondly, where it is already well established, Acacia mearnsii generates a number 
of important ecosystem services, including reduction of surface water runoff and control of erosion. It also provides functions and products of ecosystems that benefit people or yield welfare to society, including supply of wood fuel and construction materials. The role that Acacia mearnsii plays in maintaining the population of pollinators is an ecosystem function that should not be underestimated, and should be considered as one of the most important reasons for maintaining stands of the species.

\section{Ecosystem services}

Due to the ecosystem services that are rendered by Acacia mearnsii to the environment there are a number of considerations that need to be made about its control or eradication. First, the sustenance of populations of insect pollinators is both economically and ecologically important. In this regard, it is critical to note that pollinators play a crucial role in agriculture, which is the mainstay of the economy of the eastern Free State region, as well as in maintaining ecosystem health. Even though Acacia mearnsii alters habitats in places that it invades and makes it difficult for some organisms to survive, the species creates new habitats as well. Carlos et al. (2014) have shown that even though invasive plants have detrimental environmental effects there is evidence to suggest that these plants benefit wildlife under certain circumstances, especially where they are a food source or where they provide habitat for breeding, roosting and perching or where they provide refuge from predators.

Secondly, the use of mechanical and chemical methods to control Acacia mearnsii is not only expensive, since a huge amount of money has to be invested in it, but environmentally costly as well. Acacia mearnsii plays an important environmental role in reducing soil erosion. Where it is deemed absolutely necessary to eradicate trees along streams, alternative mechanical methods, for instance use of gabion blocks, should be employed to prevent erosion. Gabion blocks are cairns of rock that are encased in wire mash and erected across slopes to prevent soil creep and slumping. They reduce surface runoff and enhance water infiltration and percolation. Even though this approach is labour intensive and has the ability to create jobs for the unemployed, and the technology involved is widely used in South Africa, it is expensive to implement.

Thirdly, the eradication or control of Acacia mearnsii should be considered alongside the economic value of the products from the species, especially poles, charcoal and tannin bearing extracts such as bark. Where the eradication of the species is necessary, the villagers who are employed in the eradication projects should be given incentives to ensure that their efforts are effective. Possible incentives include ownership of the proceeds derived from the eradication, as well as assistance in the marketing of the products. NGOs could assist with the beneficiation, branding and marketing of the products. Through NGO advocacy, eco-friendly industrial establishments could be lobbied so that they give preferential treatment to products derived from operations that promote wildlife conservation or save national parks. Such an approach would simultaneously address the challenges of poverty and the environmental threats posed by bio-invasion. However, caution must be exercised where this approach is adopted. Nuñez et al. (2012) have given two reasons why this approach is problematic. One of the reasons is that if the target species becomes an economic resource, people may try to recreate its market in previously uninvaded regions, thus worsening the invasion. The other reason is that the use of invasive species as an economic resource may trigger the local community to protect these harmful species, to facilitate their incorporation into the local culture, thus generating worse environmental problems.

\section{Eco-agricultural landscaping}

At the local level, land-use planning could be incorporated into integrated programmes for bio-invasion control. As mentioned above, 
expenditure on eradication ventures has not been commensurate with results. Careful land use planning could reduce the costs of eradication. One way of doing so is the re-zoning of the areas abutting the park and to transform them into a cultivated buffer zone. By doing so, the costs of eradicating Acacia mearnsii and other IAS as well, will be passed on to the farmers. Prices of land in the created buffer zone could be lowered to ensure that crop farming in this zone becomes attractive enough to sustain arable conservation. The crops that would be grown in this zone are those that are least susceptible to wildlife damage. This approach to environmental protection and conservation is not new. Taylor-Lovell and Sullivan (2006) have noted that conservation buffers can have a positive impact on the ecological health of rural landscapes due to the role they play in reducing erosion, improving water quality, increasing biodiversity, and expanding wildlife habitats. Studies in Mesoamerica have shown that agricultural landscapes can serve as buffers for remaining natural areas (Harvey et al. 2008). Scherr and McNeely (2008) termed these landscapes eco-agricultural landscapes, because of the role they play in promoting both agriculture and conservation. An example of an agricultural landscape that has been effectively used as a buffer zone comprises small-scale tea growers who were allocated farms around Chirinda forest in Zimbabwe in order to prevent the destruction of the forest (Mukwada 2000). In the case of the conservation buffer that could be created around the GGHNP, the villagers who will be affected by the setting up of the conservation buffer and land-use re-zoning could be relocated to other areas, for example the nearby former experimental farms and agro-villages that are currently not operational. This relocation could be managed by the Department of Rural Development and Land Reform through the ongoing land reform programme. However, this approach to conservation has pros and cons.

There are arguments "for and against negative social impacts of protected areas in different parts of the world, and the scope and characteristics of these impacts" (Rantala et al. 2013: 97), especially in cases where communities have to be relocated. There has to be sufficient justification for compromising the rights of the people who have to be relocated. The extent to which community displacement for wildlife protection is defensible is highly controversial and debatable. Though the practice of conservation through displacement remains a common place in developing countries, its practice can adversely affects people's welfare, particularly that of socio-economically marginalised people (Lam \& Paul 2014). The moral justification of relocating people from their homeland in order to promote conservation has been widely questioned (Cernea \& Schmidt-Soltau 2003). Lam and Paul (2014) cite the application of the 'Impoverishment, Risks and Reconstruction' (IRR) model that was first proposed by Michael Cernea in the 1990s as a typical example of attempts by policy makers to reconstruct rural livelihoods in order to minimize the social difficulties of people displaced during a resettlement process. Loss of power and control over what people consider to be their environments in order to accommodate conservation regulations has been the source of conflict in the GGHNP. However, Brockington and Igoe (2006) argue that if conservation does not provoke protest, then it would not be doing its job properly, since providing space for nature constraints people's lives and activities. On the other hand, if conservation strategies lead to the distress of people, "especially those who are less powerful, politically marginalized, and poor, little that conservationists argue on behalf of biodiversity makes sense" (Agrawal \& Redford 2009: 1). Adams and Hutton (2007) argue that within the context of protected areas the relationship between people and nature is political and embraces a number of facets, including issues of rights and access to land and resources. It can be inferred from a recent study in the GGHNP by Mukwada et al. (2016) that the relationship between local communities and the park is a political one 
because it relates to their exclusion from the park. Kabra (2009: 250) describes such an approach to conservation as preservation via displacement and refers to it as "the most extreme version of the dominant conservation paradigm of 'fortress' or exclusionary conservation". Solutions that are based on exclusion by creating what Kabra (2009) termed 'people-free' zones displace people and undermine their livelihoods. Thus, even though there may be plausible scientific arguments for the relocation of communities that are juxtaposed to the GGHNP, the moral grounds on which this can be pursued are shaky.

The fundamental question that arises then is: how can the control of Acacia mearnsii be achieved without displacing communities or undermining their livelihoods? Holmes (2013) suggests that it is important to understand the relationship between protected areas and local communities. This author notes that the relationship between protected areas and local communities is vital for biodiversity conservation due to its capacity to maximize the benefits of biodiversity in conservation, as well as its capacity to minimize the social costs often incurred by the most marginalized groups in populations that live in and around protected areas. Due to the fact that the relationship between protected areas and local communities is context specific, it can be argued that there is no one-size-fit-all solution that maximizes the benefits of protecting the park from Acacia mearnsii invasion while minimizing the cost of this endeavour to society. However, one solution that could be made involves the segmentation of the GGHNP and setting aside a portion of land in the park to which the affected villagers are relocated with assistance from government departments. In this regard the role of government departments would be provision of housing and services to the affected villagers. The new settlement created could be a cultural village from which cultural tourism is promoted, thus diversifying tourism attractions around the park.

\section{Conclusion}

The focus of this paper is the discussion of the distribution of Acacia mearnsii in the GGHNP, the challenges associated with its control, as well as the options that can be adopted to control the species. There are some conclusions that can be drawn from the foregoing discussion regarding the invasion, control and eradication of Acacia mearnsii. Firstly, the eradication of the species may not be completely desirable in some areas, especially when considering the importance of the species to rural livelihoods, its value to the agricultural economy and its role in maintaining ecosystem health. Secondly, for the control and management of Acacia mearnsii to be successful it must be viewed as an integral component of land-use planning and incorporated into already existing social and rural development programmes, such as the Expanded Public Works and land reform programmes. Finally, we conclude that the economic, social and environmental dimensions of Acacia mearnsii should be factored into programmes designed to control or eradicate the species, since the invasion by this species is a multi-faceted problem which requires a multi-faceted solution.

\section{Acknowledgements}

The authors are grateful to SANParks for allowing them to conduct the research in the Golden Gate Highlands National Park and for the providing vehicles and personnel resources that were used during fieldwork. We are also grateful to the villagers from the local community for according us their time and attention during the data collection stage of the research.

\section{Editors' note:}

Unless otherwise stated, the sources of tables and figures are the authors', on the basis of their own research. 


\section{References}

Adams W.M., Hutton J., 2007. People, parks and poverty: Political ecology and biodiversity conservation. Conservation and Society, vol. 5, no. 2, pp. 147-183.

Agrawal A., Redford K., 2009. Conservation and displacement: An overview. Conservation and Society, vol. 7, no. 1, pp. 1-10.

Alofs K.M., Fowler N.L., 2010. Habitat fragmentation caused by woody plant encroachment inhibits the spread of an invasive grass. Journal of Applied Ecology, vol. 47, no. 2, pp. 338-347.

Antonopoulos R., 2009. Promoting gender equality through stimulus packages and public job creation. Public Policy Brief, no. 101. New York: Jerome Levy Economics Institute of Bard College.

Blackburn T.M., Pyšek P., Bacher S., Carlton J.T., Duncan R.P., JaRoŠIK V., WILSON J.R.U., RICHARDSON D.M., 2011. A proposed unified framework for biological invasions. Trends in Ecology and Evolution, vol. 26, no. 7, pp. 333-339.

Brockington D., IgOe J., 2006. Eviction for conservation: A global overview. Conservation and Society, vol. 4, no. 3, pp. 424-470.

Campbell P., 2000. Wattle control: Handbook No. 3. Pretoria: Plant Protection Research Institute.

Carlos E.H., Gibson M., Weston M.A., 2014. Weeds and wildlife: Perceptions and practices of weed managers. Conservation and Society, vol. 12, no. 1, pp. 54-64.

Cernea M.M., Schmidt-Soltau K., 2003. The end of forcible displacements? Conservation must not impoverish people. Policy Matters, vol. 12, pp. 42-51.

Drury K.L.S., Drake J.M., Lodge D.M., Dwyer G., 2007. Immigration events dispersed in space and time: Factors affecting invasion success. Ecological Modelling, vol. 206, no. 1-2, pp. 63-78.

DWAF, 1997. The Working for Water Programme: Annual Report 1996/97. Pretoria: Department of Water Affairs and Forestry.

Forsyth G.G., Le Maitre D.C., O'Farrell P.J., van WILGEN B.W., 2012. The prioritisation of invasive alien plant control projects using a multicriteria decision model informed by stakeholder input and spatial data. Journal of Environmental Management, vol. 103, pp. 51-57.
FOXCROFT L.C., 2009. Developing thresholds of potential concern for invasive alien species: Hypotheses and concepts. Koedoe, vol. 51, no. 1, pp. 11-16.

Harvey C.A., Komar O., Chazdon R., Ferguson B.G., Finegan B., Griffith D.M., MartínezRamos M., Morales H., Nigh R., Soto-Pinto L., VAN BREUGel M., Wishnie M., 2008. Integrating agricultural landscapes with biodiversity conservation in the Mesoamerican hotspot. Conservation Biology, vol. 22, no. 1, pp. 8-15.

HOLmES G., 2013. Exploring the relationship between local support and the success of protected areas. Conservation and Society, vol. 11, no. 1, pp. 72-82.

KabRA A., 2009. Conservation-induced displacement: A comparative study of two Indian protected areas. Conservation and Society, vol. 7, no. 4, pp. 249-267.

Lam L.M., Paul S., 2014. Disputed land rights and conservation-led displacement: A double whammy on the poor. Conservation and Society, vol. 12, no. 1, p. 65-76.

Lele S., Springate-Baginski O., Lakerveld R., Deb D., DASH P., 2013. Ecosystem services: Origins, contributions, pitfalls, and alternatives. Conservation and Society, vol. 11, no. 4, pp. 343-358.

LiU H., LIN Z., QI X., Zhang M., YANG H., 2012. Interactive effects of habitat destruction and competition on exotic invasion. Ecological Informatics, vol. 9, pp. 69-75.

Liv S., Sheppard A., Kritikos D., Cook D., 2011. Incorporating uncertainty and social values in managing invasive alien species: a deliberative multi-criteria evaluation approach. Biological Invasions, vol. 13, no. 10, pp. 2323-2337.

Lovell S.T., Sullivan W.C., 2006. Environmental benefits of conservation buffers in the United States: Evidence, promise, and open questions. Agriculture, Ecosystems and Environment, vol. 112 , no. 4, pp. 249-260

luque G.M., Bellard C., Bertelsmeier C., Bonnaud E., Genovesi P., Simberloff D., CourCHAMP F., 2013. The 100th of the world's worst invasive alien species. Biological Invasions, vol. 16, no. 5, pp. 981-985.

Moyo H.P.M., FatunBi A.O., 2010. Utilitarian perspective of the invasion of some South African biomes by Acacia mearnsii. Global Journal of Environmental Research, vol. 4, no. 1, pp. 6-17. 
Mukwada G., 2000. Natural Resources Conservation and Management. Harare: Zimbabwe Open University.

Mukwada G., Chingombe W., Taru P., 2016. Strifes of the frontier: an assessment of Acacia mearnsii related park-community conflicts in the Golden Gate Highlands National Park, South Africa. Journal of Integrative Environmental Sciences, vol. 13, no. 1, pp. 37-54.

Nuñez M.A., Kuebbing S., Dimarco R.D., SimberLOFF D., 2012. Invasive Species: to eat or not to eat, that is the question. Conservation Letters, vol. 5, no. 5, pp. 334-341.

Ogden J.A.E., Rejmánek M., 2005. Recovery of native plant communities after the control of a dominant invasive plant species, Foeniculum vulgare: Implications for management. Biological Conservation, vol. 125, no. 4, pp. 427-439.

Pejchar L., Mooney H.A., 2009. Invasive species, ecosystem services and human well-being. Trends in Ecology and Evolution, vol. 24, no. 9, pp. 497-504.

Prévot-Julliard A.-C., Clavel J., Teillac-DesChAMPS P., JULLIARD R., 2011. The need for flexibility in conservation practices: Exotic species as an example. Environmental Management, vol. 47, pp. 315-321.

Rantala S.E., VihemäKI H., Swallow B.M., JamBIYA G., 2013. Who gains and who loses from compensated displacement from protected areas? The case of the Derema corridor, Tanzania. Conservation and Society, vol. 11, no. 2, pp. 97-111.

RICHARDSON D.M., VAN WILGEN B.W., 2004. Invasive alien plants in South Africa: how well do we understand the ecological impacts? South African Journal of Science, vol. 100, no. 1, pp. 45-52.

Riddell M., 2013. Assessing the impacts of conservation and commercial forestry on livelihoods in northern Republic of Congo. Conservation and Society, vol. 11, no. 3, pp. 199-217.

Rouget M., Richardson D.M., Nel J.L., Van WiLGEN B.W., 2002. Commercially important trees as invasive aliens - towards spatially explicit risk assessment at a national scale. Biological Invasions, vol. 4, no. 4, pp. 397-412.

RSA, 1983. Conservation of Agricultural Resources (Act No. 43 of 1983). Pretoria: Republic of South Africa.

SANParks, 2008. Golden Gate Highlands National Park Management Plan. Pretoria: SANParks.

SANParks, 2012. Golden Gate Highlands National Park Management Plan: Draft 4.4. Pretoria: SANParks.

SANParks, 2013. Golden Gate Highlands National Park Management Plan: 2013-2023. Pretoria: SANParks.

SCherR S.J., MCNeEly J.A., 2008. Biodiversity conservation and agricultural sustainability: towards a new paradigm of 'ecoagriculture' landscapes. Philosophical Transactions of the Royal Society B, vol. 363, no. 1491, pp. 477-494.

Schüttler E., Rozzi R., Jax K., 2011. Towards a societal discourse on invasive species management: A case study of public perceptions of mink and beavers in Cape Horn. Journal for Nature Conservation, vol. 19, no. 3, pp. 175-184.

SLATER R., 2002. Between a rock and a hard place: contested livelihoods in Qwaqwa National Park, South Africa. The Geographic Journal, vol. 168, no. 2, pp. 116-129.

Teel T.L., Manfredo M.J., Jensen F.S., Buiss A.E., Fischer A., Riepe C., Arlinghaus R., Jacobs M.H., 2010. Understanding the cognitive basis for human-wildlife relationships as a key to successful protected-area management. International Journal of Sociology, vol. 40, no. 3, pp. 104-123.

van Wilgen B.W., Forsyth G.G., Le Maitre D.C., Wannenburgh A., Kotzé J.D.F., van den Berg E., Henderson L., 2012. An assessment of the effectiveness of a large, national-scale invasive alien plant control strategy in South Africa. Biological Conservation, vol. 148, no. 1, pp. 28-38.

van Wilgen B.W., Reyers B., Le Maitre D.C., RichARdson D.M., Schonegevel L., 2007. A biomescale assessment of the impact of invasive alien plants on ecosystem services in South Africa. Journal of Environmental Management, vol. 89, no. 4, pp. 336-349.
(C) Geoffrey Mukwada • Wisemen Chingombe - Phillip Taru

(C) Geographia Polonica

(C) Institute of Geography and Spatial Organization

Polish Academy of Sciences • Warsaw • 2016
Article first received • January 2015 Article accepted • May 2016

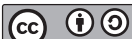

